January 1996

\title{
The Uneasy Place of Principle in Tort Law
}

George C. Christie

\section{Recommended Citation}

George C. Christie, The Uneasy Place of Principle in Tort Law, 49 SMU L. REV. 525 (1996)

https://scholar.smu.edu/smulr/vol49/iss3/10

This Article is brought to you for free and open access by the Law Journals at SMU Scholar. It has been accepted for inclusion in SMU Law Review by an authorized administrator of SMU Scholar. For more information, please visit http://digitalrepository.smu.edu. 


\title{
The Uneasy Place of Principle in TORT LAW
}

\author{
George C. Christie*
}

$\mathrm{T}$

This article is about the instinctive urge of lawyers to find some coherent and self-contained logical structure in the law. Sir Edward Coke asserted, for example, that the common law is "an artificial perfection of reason, gotten by long study, observation, and experience."1 Coke, in turn, was attacked by Thomas Hobbes as being a proponent of what in our time would be called "sterile formalism." 2 Nevertheless, throughout history the notion that the common law represents the application of general principles in some non-formalistic sense to the decision of concrete cases has continued to capture the imagination of the legal profession. Of course, the intensity of the urge to find principles at the core of legal development waxes and wanes in any given area of the law at any given time and, in some areas of the law, it is greater than it is in others. There have always, however, been skeptics. It is no mere hap-

* James B. Duke Professor of Law, Duke University School of Law, Durham, N.C. I am honored to have been asked to contribute to this issue of the $S M U$ Law Review honoring the memory of my friend, former colleague, and sometime co-author (Presumptions and Assumptions in the Criminal Law: Another View, 1970 Duke L.J. 919), Ken Pye. The present essay is a revised and somewhat expanded version of a paper that was published in Philosophical Foundations of Tort Law (Oxford Univ. Press, 1995) that was edited by David Owen, a former student of Mr. Pye and mine. I wish to thank Jane Stapleton and Martin Stone for their careful reading of early drafts of this essay and for their many helpful comments.

1. 1 Sir Edward Coke, Systematic Arrangement of Lord Coke's First InstiTUte OF The Laws of ENGLand \$\$ 97b, $183 \mathrm{~b}$ (J.H. Thomas ed., 1836) [hereinafter First INSTITUTE]. Expanded, the quote reads:

Reason is the life of the law, nay, the common law itself is nothing else but reason; which is to be understood of an artificial perfection of reason, gotten by long study, observation, and experience, and not of every man's natural reason; ... . And therefore, if all the reason that is dispersed into so many several heads, were united into one, yet could he not make such a law as the law of England is; because, by many successions of ages, it hath been fined and refined by an infinite number of grave and learned men ....

The First Institute was of course a commentary on Littleton on Tenures. In the "new arrangement," by J.H. Thomas in 1818, of the First Institute, the quoted material appears as the first paragraph of Book I, Chapter I.

2. Thomas HobBes, Leviathan 147-48 (Ernest Rhys ed., 1914). Hobbes attacks Coke's assertion, in First Institute $\S 709$, that a person who flees to avoid a felony persecution, but is subsequently acquitted of the felony, must nevertheless forfeit his goods because the law does not permit him, in the forfeiture proceedings, to challenge the presumption of guilt raised by his initial flight. Hobbes makes the same criticism in his $A$ Dialogue Between a Philosopher and a Student of the Common Laws of England, in 6 THE English Works of Thomas Hobbes of MAlmesbury 136-37 (Sir William Molesworth ed., 1840). 
penstance that one of the most frequently cited statements in all of legal literature is Holmes' aphorism that "[t]he life of the law has not been logic: it has been experience." 3

In the last thirty years, there has been an increased interest among scholars, judges, and practicing lawyers concerned with the law of torts to find the principles that underlie that law. Sometimes, as with some in the law and economics school, the endeavor starts out as an attempt to discover the principles that can organize legal experience and explain the decision of actual cases even if those principles were not (even "unconsciously") in the minds of the judiciary. An example is the claim that the law of negligence can be explained on the assumption that the law is seeking to achieve the more efficient allocation of society's resources. ${ }^{4}$ Of course, it is only a small step from the observation that the cases can be usefully organized around such a principle to the conclusion that, if not consciously, at least "unconsciously," judges were actually motivated by such a principle. From there it is only another small step for a proponent of economic efficiency, as the key to legal development, to put forth the normative claim that judges should be motivated by such a principle.

There are other principles, however, which start out from the beginning as being primarily normative principles, even if it is thought that they also serve an explanatory purpose. Recent experience brings to mind a number of such normative principles that have been urged upon the profession by scholars and judges. If someone were to remark that most of these instances seem to be examples of the Duke of York marching ten thousand men up a hill only to march them down again, such a person would not be alone. 5 To see why someone might be tempted to make this observation, it will be useful to examine some of these well-known recent attempts to subject the law of torts to the discipline of principles. This is what I propose to do after a few preliminary remarks, which will clear the way for the central part of the discussion.

\section{SOME PRELIMINARY OBSERVATIONS ON THE USES OF PRINCIPLE IN TORT LAW}

It is of course necessary to recognize that, even if one can agree on an appropriate principle, one still has to determine the exact canonical formulation of that principle, as well as how that principle should be applied to concrete fact situations. By themselves these are not insurmountable objections to the appeal to principle. I advert to these possible objections to make clear from the outset that it shall be no part of my thesis to claim

3. Oliver W. Holmes, JR., The Common Law 1 (1881).

4. Richard A. Posner, $A$ Theory of Negligence, 1 J. Legal Stud. 29 (1972); see also Parts I and II of Richard A. PosNer, Economic ANAlysis OF LAW (2d ed. 1972).

5. See David Howarth, Negligence after Murphy: Time to Rethink, 50 CAMBRIDGE L.J. 58, 87 (1991), an article that used a shortened version of this old saw. Howarth's article is primarily concerned with the state of negligence law after recent developments, many of which I will discuss below, rather than with the normative status of principle that is the focus of this paper. 
that they are. For example, in McDougald $v$. Garber, ${ }^{6}$ the New York Court of Appeals enunciated the principle that, in order to recover for loss of enjoyment of life-which the court considered a subcategory of pain and suffering - the injured plaintiff must have "cognitive awareness." 7 No such damages could be recovered by a comatose person. What level of cognition is necessary so that a person might be held to have "cognitive awareness" is nevertheless obviously a difficult matter. The difficulty was highlighted in the dissent's submission that the award of substantial sums for pain and suffering to people with very slight awareness of their predicament, which the majority recognized would be permissible, can hardly be said to give effect to the policy considerations underlying the court's decision-are these second order principles or the original principle in different guise? - that general damages in negligence cases should have some "meaning or utility to the injured person." 8 The majority recognized the validity of the objection but declared that considerations of efficiency of application precluded the adoption of a more fine-tuned test. Whether or not one agrees with the principles adopted by the majority, its response to the dissent's argument seems fair enough. Every general principle will confront cases in which its application will run at cross purposes with its aspirations, and this feature is not by itself a conclusive reason either to abandon the principle or even necessarily to refuse to apply it in those cases. The real world is not such a neat and tidy place.

A second preliminary observation is that many of the objections to the use of particular principles in the decision of tort cases arise from oversimplified characterizations of the facts of particular cases that end up by making legal disputes into verbal disputes. For example, a much more important principle of modern tort law than the one at stake in $\mathrm{McDou}$ gald v. Garber, and one to which I devote a great deal of attention in the succeeding portions of this article, is the principle that both the question of fault-where that is in issue-and the question of causation, in modern tort law, should be governed by foreseeability. The late Dean Prosser attacked the use of the concept of foreseeability, as applied to questions of legal causation, on the ground that "[i]n one sense, almost nothing is entirely unforeseeable, since there is a very slight mathematical chance, recognizable in advance, that even the most freakish accident which is possible will occur, particularly if it has ever happened in history before." 9 Prosser's objection, that the foreseeability test "lacks all clarity and precision," 10 reminds one of the similar criticisms made by Judge Friendly in 1964 in In re Kinsman Transit Co., ${ }^{11}$ where he commented that some American courts had applied the foreseeability test so as to

\footnotetext{
6. 536 N.E.2d 372 (1989).

7. Id. at 375 .

8. Id. at 378 .

9. William L. Prosser, Handbook of THE LaW of ToRTs 267 (4th ed. 1971).

10. Id.

11. 338 F.2d 708 (2d Cir. 1964), cert. denied, 380 U.S. 944 (1965).
} 
"extend that concept to such unforeseen lengths as to raise serious doubt whether the concept is meaningful." 12 The case cited to support this assertion was In re Guardian Casualty Co., ${ }^{13}$ in which, to quote Judge Friendly,

the majority gravely asserted that a foreseeable consequence of driving a taxicab too fast was that a collision with another car would project the cab against a building with such force as to cause a portion of the building to collapse twenty minutes later, when the cab was being removed, and injure a spectator twenty feet away. Surely this is 'straining the idea of foreseeability past the breaking point,' ... at least if the matter be viewed as of the time of the negligent act, as the supposedly symmetrical test of The Wagon Mound demands $\ldots{ }^{14}$

Judge Friendly's strictures notwithstanding, the example he gives does not support the conclusion at which he wishes to arrive. First of all, any concept will of course present some difficulties in application. As we have already noted, this by itself is not a sufficient reason to reject it. Furthermore, the case he mentions is not at all bizarre. Of course, if one had to foresee the exact manner in which every accident occurred or the exact person who would be injured, very few things would be antecedently "foreseeable." But, in the type of case that Judge Friendly posited, surely it is foreseeable that a motor vehicle that travels too rapidly in an urban setting might crash into the side of a building, and it is surely foreseeable that the crash itself might dislodge some of the bricks in the building, or that, in the process of extracting a vehicle that has embedded itself in a structure, some bricks might be displaced that would then fall on pedestrians. If one characterizes the situation as I have-which not only does not seem unfair but also seems to conform to what common sense would suggest - then the accident seems neither bizarre nor unusual and certainly not unforeseeable ex ante. The problems with a foreseeability test to which I shall now turn are, however, not of this order and cannot be removed by a more careful statement of the factual issues before the court.

\section{THE MODERN ODYSSEY OF THE FORESEEABLE PRINCIPLE}

\section{A. British Cases on Economic Loss}

Once it became generally settled in England, as in the United States, that, at least in some circumstances, recovery could be had for the economic loss suffered as a consequence of negligent misrepresentation, ${ }^{15}$ the question arose whether "pure" economic loss might be recoverable in

12. Id. at 724 .

13. 2 N.Y.S.2d 232, aff d, 16 N.E.2d 397 (1938).

14. Kinsman, 338 F.2d at $724-25$ n.10 (citation omitted).

15. See Hedley Byrne \& Co. Ltd. v. Heller \& Partners Ltd., 1964 App. Cas. 465 (1963); Restatement (SECOND) OF TORTS $\S 552$ (1977). 
other types of actions based on a negligence theory. For my purposes, the judgment of the Court of Appeal in Spartan Steel \& Alloys Ltd. v. Martin \& Co. (Contractors) Ltd. ${ }^{16}$ is a convenient starting point for examining the flurry of judicial and scholarly concern, which is only now beginning to subside, with the issue of when economic loss may be recovered. Although some of the leading cases are well-known, at least in England, it may be helpful to set out briefly the evolution of British judicial thinking on the legal principles that should govern legal development in this area.

In Spartan Steel, the defendants' employees severed a power cable. The plaintiffs, who were the owners of a nearby factory, incurred some physical damage when molten metal in their furnaces cooled. The defendants conceded that they were liable for this damage. The plaintiffs, however, also sought to recover the lost profits they would have made if they could have fabricated the metal that was spoiled and sold it as finished goods. They further sought recovery for the lost profits for metal that they would have been able to melt and fabricate during the time that their factory was inoperative due to the defendants' negligence. The trial court allowed recovery of all requested items of damages. The defendants appealed the portion of the trial court's judgment that allowed any damages for lost profits. The Court of Appeal allowed the claim for lost profits on the metal that was damaged, but a majority of the court denied recovery for any other loss of profits during the period that the factory was inoperative owing to absence of electric power. Lord Denning, M.R., found unhelpful analyses that would deny recovery for lost profits on the basis that there was either "no duty" or that the damage was "too remote." He thought that such tests should be discarded and that the time had come "to consider the particular relationship in hand, and see whether or not, as a matter of [public] policy, economic loss should be recoverable." 17 He thus concluded that the lost profits on the metal that the plaintiffs would have been able to process and fabricate but for the fact that their power was cut off could not be recovered "because that was economic loss independent of the physical damage." 18

Edmund Davies, L.J., dissented on this point. He noted that it was common ground that the lost profits on the metal that was ruined in the process of fabrication and the lost profits on the metal that the plaintiffs were unable to process and fabricate "were equally foreseeable and equally direct consequences of the defendants' admitted negligence."19 Admittedly, the former profit was lost as a result of physical damage done to the material in the furnace when the power was cut off. "But what," he asked, "has that purely fortuitous fact to do with legal princi-

16. 1973 Q.B. 27 (1972) (Eng. C.A.).

17. Id. at 37.

18. Id. at 39. Why he was prepared to allow recovery for the loss of profits on the metal that was spoiled is an interesting question. Given recent developments that would seem incorrect.

19. Id. at 41 . 
ple?"20 In answer to his own question he replied: "In my judgment, nothing." 21

Whatever the appeal of Lord Denning's conclusion, that whether and in what circumstances there may be recovery for economic loss must ultimately depend on policy considerations, developments in the House of Lords soon raised the question whether Lord Denning's approach was in point of fact the correct one. Anns v. Merton London Borough Council, ${ }^{22}$ decided in 1977, involved a group of plaintiffs who were the longterm lessees of a group of flats in a housing development that had been completed in 1962. Two of the plaintiffs were original lessees, but the others acquired their leases by subsequent assignment. The block of flats had been constructed with inadequate foundations. The basis of the claim against the Merton London Borough Council was that its employees had negligently inspected and approved the foundations that had been laid by the contractor, although these foundations had not conformed to the Council's building code. The House of Lords affirmed the Court of Appeal's conclusion that, on the facts presented, the plaintiffs could bring an action in negligence against the Council.

Lord Wilberforce, who delivered the principal speech in Anns, with which all the other law lords expressed their agreement, declared that an action for negligence could "only arise when the state of the building is such that there is present or imminent danger to the health or safety of persons occupying it." 23 What gave fuel to the controversy with which we are concerned was not so much this fairly narrow holding, but Lord Wilberforce's earlier statement, citing among other authorities Lord Reid's speech in Dorset Yacht Co. Ltd. v. Home Office, ${ }^{24}$ that, in English law, "the position has now been reached that in order to establish that a duty of care arises in a particular situation, it is not necessary to bring the facts of that situation within those of previous situations in which a duty of care has been held to exist."25 Instead, Lord Wilberforce thought, one had to ask two questions. First, was there "a sufficient relationship of proximity or neighborhood such that ... [it was] in the reasonable contemplation of the [defendant that] carelessness on his part [would] be likely to cause damage to the [plaintiff] - in which case a prima facie duty of care arises"? 26 Second, if that in fact were the case, one would then have to consider "whether there are any considerations which ought to negative, or to reduce or limit the scope of the duty or the class of person to whom it is owed or the damages to which a breach of it may give rise." 27 Among the examples that he gave of situations where such limi-
20. Id.
21. Id.
22. 1978 App. Cas. 728 (1977).
23. Id. at 760 .
24. 1970 App. Cas. 1004 (1969).
25. Anns, 1978 App. Cas. at 751.
26. Id. at 751-52.
27. Id. at 752 . 
tations might be appropriate was that of negligent misrepresentation. ${ }^{28}$

Although Anns involved physical damage to property, Lord Wilberforce's speech obviously raised the question whether the traditional distinction between pure economic loss and other sorts of loss was about to be discarded and replaced by a "more principled" mode of analysis. For example, in 1981, in Lexmead (Basingstoke) Ltd. $v$. Lewis, ${ }^{29}$ Lord Diplock, who delivered the only significant speech in the House of Lords, queried whether a retailer who was obliged to indemnify his buyer for sums that the buyer had to pay to third parties injured by a negligently manufactured product might not seek to recover those damages against the manufacturer with whom the retailer was not in privity of contract. Lord Diplock raised this query because the Court of Appeal had declared that the principle of Donoghue v. Stevenson ${ }^{30}$ - under which a party, who was not in privity of contract with the negligent manufacturer of a product, could nevertheless bring an action for damages against the manufacturer-did not extend to purely economic loss. Lord Diplock went out of his way to declare that

[w]hile in the absence of argument it could not be right to express any final view, I should not wish the dismissal of the ... appeal to be regarded as an approval by this House of the proposition that where the economic loss suffered by a distributor ... consists of a liability to pay damages to the ultimate consumer for physical injuries ... such economic loss is not recoverable under the Donoghue v. Stevenson principle from the manufacturer. ${ }^{31}$

Lexmead (Basingstoke) Ltd. v. Lewis involved a case where the damage for which indemnity was sought was largely physical injury to the person, but Lord Diplock's ruminations certainly could be taken as further evidence of the siren call of a single general principle governing liability for negligence and, in particular, of the principle that liability should be determined by "reasonable foreseeability." In fact, this is the position that the House of Lords seemed to be in the process of adopting the very next year, in 1982, when it decided Junior Books Ltd. v. Veitchi Co. $L t d .{ }^{32}$ In that case, the defendant was a subcontractor who had installed a defective floor in a factory. The owner of the factory was permitted to bring an action sounding in negligence, not only for the cost of correcting the defect but also for the loss of profits suffered as a result, despite the lack of privity of contract. There was no allegation that the defective flooring created any danger to life or limb or to any other physical property. Except for a lone dissenter, all of their lordships in Junior Books expressed agreement with the speech of Lord Roskill. To the ar-

28. The House of Lords had, of course, declared that an action for negligent misrepresentation might be brought, even in the absence of some "special relationship," Hedley Byrne \& Co. Ltd. v. Heller \& Partners Ltd., 1964 App. Cas. 465 (1963), but had not yet spelled out, and may perhaps still not have (see infra note 52), the limits of that liability.

29. 1982 App. Cas. 225 (1981).

30. 1932 App. Cas. 56 (1932) (appeal taken from Scot.).

31. Lexmead, 1982 App. Cas. at 278.

32. [1983] 1 App. Cas. 520 (1982) (appeal taken from Scot.). 
gument that allowing recovery in such cases would "open the floodgates," Lord Roskill responded that, although "policy considerations have from time to time been allowed to play their part in the tort of negligence since it first developed ... . yet today I think its scope is best determined by considerations of principle rather than of policy." 33 He cited, with approval, the speeches of Lord Reid in Dorset Yacht and of Lord Wilberforce in Anns. Applying the criteria laid down by Lord Wilberforce in Anns to the facts before him, he saw "nothing whatsoever to restrict the duty of care arising from the proximity of which I have spoken." 34 In dissent, Lord Brandon of Oakbrook argued that the only duty the subcontractor had to the owner of the factory was to install the flooring so as to insure that there was no danger to persons or property, excluding the property in question, i.e., the floor itself. ${ }^{35}$

Lord Roskill in Junior Books also cited a number of Commonwealth cases of which the most well-known is Caltex Oil (Australia) Pty. Ltd. v. The Dredge "Willemstad."36 In that case, the dredge had damaged a pipeline that was owned by an oil refining company that connected the refinery with an oil terminal owned by the plaintiff on the other side of the bay. The owner of the terminal depended upon the pipeline to receive oil from the refinery. The High Court of Australia held that the owner of the terminal was entitled to recover its expenses in finding alternate means of getting oil to its terminal. ${ }^{37}$

The apparent triumph of the principle of foreseeability in the economic loss cases was foreshadowed a few months previously in McLoughlin $v$. O'Brian. ${ }^{38}$ In McLoughlin, the House of Lords allowed recovery of damages for emotional stress by a mother who had not physically witnessed the serious injury to her children and husband in an automobile accident, but first saw them a few hours later in a dazed and battered condition in the hospital where she was also informed that one of the children had been killed. The most interesting speeches were those of Lord Scarman and of Lord Bridge of Harwich, who concluded that, with regard to the question of the limits of liability for the infliction of nervous shock, there were "no policy considerations sufficient to justify limiting the liability of negligent tortfeasors by reference to some narrower criterion than that of reasonable foreseeability." 39 In an ironic twist, Lord Bridge of Harwich expressed regret that Lord Edmund-Davies, as he now was, whose dissent in Spartan Steel was the starting point of our discussion, criticized his conclusion. Not only did Lord Edmund-Davies criticize Lord Bridge of Harwich's conclusion, he also rather pointedly disagreed with the conclu-

33. Id. at 539 .

34. Id. at 546.

35. Id. at 549 .

36. 136 C.L.R. 529 (1976) (Austl.). This case pre-dated Anns but was not cited in it.

37. The High Court tried to limit the sweep of its decision by declaring that reasonable foreseeability of economic loss was not enough. There had to be a sufficient relationship of "proximity" between the parties. Id. at 574-75 (Stephen, J.); cf. id. at 553-56 (Gibbs, J.). 38. [1983] 1 App. Cas. 410 (1982).

39. Id. at 443. 
sion of Lord Scarman, who in a brief speech expressing his agreement with Lord Bridge of Harwich asked, "Why then should not the courts draw the line, as the Court of Appeal [which denied recovery on policy grounds] manfully tried to do in this case?" 40 To which question Lord Scarman declared, "[s]imply, because the policy issue as to where to draw the line is not justiciable. The problem is one of social, economic, and financial policy. The considerations relevant to a decision are not such as to be capable of handling within the limits of the forensic process." 41 To which Lord Edmund-Davies replied that this proposition was "as novel as it is startling." $42 \mathrm{He}$ found it novel because it had never been mentioned in argument and "startling because in my respectful judgment it runs counter to well-established and wholly acceptable law."43

Junior Books turned out to be the crest of the attempt to "rationalize" the law of tort concerning the recovery of economic damages by application of the "reasonable foreseeability" principle. The first retreat took place in Governors of the Peabody Donation Fund v. Sir Lindsay Parkinson \& Co., ${ }^{44}$ a case very similar to Anns but with one, as it turned out, significant difference: the plaintiff was a foundation, not a group of individual homeowners. In denying recovery, Anns was distinguished on precisely those grounds. ${ }^{45}$ The following year in Candlewood Navigation Corp. v. Mitsui O.S.K. Lines Ltd. ${ }^{46}$ a time charterer sought to recover the economic loss sustained when the ship it had chartered had to be taken out of service for repairs after a collision with the defendant's negligently navigated vessel. Although the case arose in Australia, the Privy Council refused to accept the reasoning of the Australian judges in the Caltex case. Instead, citing English precedent and Justice Holmes' opinion in the Robins Drydock case, ${ }^{47}$ the Privy Council reaffirmed the traditional view that the time charterer could not recover its economic loss. The proposition that a person with no physical property that was damaged could not recover in tort for economic loss consequent to the damage of property owned by another was soon thereafter reaffirmed by the House of Lords. ${ }^{48}$

While these developments were taking place in Great Britain, the United States Supreme Court in East River S.S. Corp. v. TransAmerica

40. Id. at 431 .

41. Id.

42. Id. at 427. Lord Edmund-Davies nevertheless supported the decision to allow recovery in the case because, on policy grounds, he reached a different conclusion than the Court of Appeal.

43. Id. In a subsequent case, their lordships were able to avoid ruling on whether the principle of foreseeability would enable someone who saw a disaster "live" on television to recover against the culpable party by reliance on the practice of the television authorities not to show pictures of suffering by recognizable individuals. Alcock v. Chief Constable of So. Yorkshire Police, [1992] 1 App. Cas. 310 (1991).

44. 1985 App. Cas. 210 (1984).

45. Id. at 234 .

46. 1986 App. Cas. 1 (P.C. 1985) (appeal taken from N.S.W.).

47. Robins Dry Dock \& Repair Co. v. Flint, 275 U.S. 303 (1927).

48. Leigh \& Sillavan Ltd. v. Aliakmon Shipping Co., [1986] 1 App. Cas. 785 (1986). 
Delaval, Inc. ${ }^{49}$ held that damages for economic loss cannot be awarded in a product liability action brought in admiralty regardless of whether the action was brought under a strict liability theory or a negligence theory. The plaintiffs in that case had entered into long-term bare-boat charters of tankers that turned out to have defective turbines. The plaintiffs were not only unable to recover their lost profits while the ships were being repaired, but also were denied recovery for the cost of repairing the defective engines. The Court was unwilling to displace the operation of warranty law in an action involving commercial parties. Relying in part on East River, the House of Lords in 1988 then decided $D \& F$ Estates Ltd. v. Church Commissioners for England, ${ }^{50}$ a case involving a block of flats in which the plaster work had been done negligently by one of the subcontractors. Their Lordships held that, in the absence of a contractual relationship between the parties, the cost of repairing a defect in physical property that was discovered before the defect had caused personal injury or physical damage to other property was not recoverable in a negligence action by a remote purchaser or lessee.

Finally, in 1990, the House of Lords was presented with Murphy v. Brentwood District Council, ${ }^{51}$ a case even more similar to Anns because the plaintiff was an individual person who sought recovery for the loss he suffered in selling his house for a lower price than he would have received had it not been in a defective condition. The trial court specifically found that, in its defective state, the house had posed an imminent danger to plaintiff during the time he occupied it. In reversing the judgment of the Court of Appeal, which in turn had affirmed the trial court's award of damages, the House of Lords held that Anns had been wrongly decided and that the subsequent cases relying upon it should be overruled. Lord Keith of Kinkel, with whose speech all the other law lords expressed agreement, expressly declared that "although the damage in Anns was characterized as physical damage by Lord Wilberforce, it was purely economic loss." 52 Lord Keith of Kinkel concluded:

It is clear that Anns did not proceed upon any basis of established principle, but introduced a new species of liability governed by a principle indeterminate in character but having the potentiality of covering a wide range of situations, involving chattels as well as real property, in which it had never hitherto been thought that the law of negligence had any proper place. ${ }^{53}$

He noted that the logical implication of what he thought was "a somewhat superficial examination of principle" in the Anns case was a "collision with long established principles regarding liability in the tort of

49. 476 U.S. 858 (1986).

50. [1989] 1 App. Cas. 177 (1988).

51. [1991] 1 App. Cas. 398 (1990).

52. Id. at 466.

53. Id. at 471 . 
negligence for economic loss." 54

With the decision of Murphy, the Duke of York had seemingly returned to the bottom of the hill. Given this history, British scholars have asserted, with particular reference to the House of Lords' decisions in Caparo Industries $P L C$ v. Dickman, ${ }^{55}$ a negligent misrepresentation case, and Alcock v. Chief Constable of South Yorkshire, ${ }^{56}$ an emotional distress case, that the only general principle recognized by the House of Lords for organizing the extent of liability in negligence cases is that of "proximity," a concept that is lacking in substance. ${ }^{57}$ In a more recent case, for example, the House of Lords held in Spring v. Guardian Life Insurance $P L C^{58}$ that a former employee could bring an action against his former employer for the negligent preparation of a letter of reference that, but for the defense of qualified privilege, could have been the basis of an action for libel. Lord Keith of Kinkel dissented on the ground that the law of defamation should not be superseded by resort to the law of negligent misrepresentation, a position for which, I must confess, I have considerable sympathy. The majority, nevertheless, held to the contrary and relied on a mélange of factors, such as foreseeability, proximity, public policy, conceptions of fairness, etc.

Unlike, perhaps, the British authors, I see no reason why cases involving the types of economic loss that are the principal focus of this article need necessarily be decided by the same considerations as those governing recovery for negligent misrepresentation, let alone those governing recovery for the negligent infliction of emotional distress. I thus would not disagree with those who assert that the alternatives to reasonable foreseeability are even more unsatisfactory. My point, rather, is that the attempt to establish a single general principle of liability for all negligent actions has shown itself to be as hopeless as it is, in my judgment, unwise. As to the hopelessness of the task, consider two even more recent decisions of the House of Lords.

In the first, it was held, with two dissents, that a solicitor, who negligently delayed preparing a new will until the testator died, was liable to the disappointed prospective beneficiaries on the grounds that the solici-

54. Id. The Murphy case was then applied in Department of the Env't v. Thomas Bates \& Son, Ltd., [1991] 1 App. Cas. 499 (1990). Some Commonwealth courts have, however, refused to follow Murphy and have continued to allow recovery against local governmental authorities in defective housing cases. See I.N. Duncan Wallace, No Somersault after Murphy: New Zealand Follows Canada, 111 Law Q. Rev. 285 (1995).

55. [1990] 2 App. Cas. 605 (1990). Their Lordships held that shareholders who bought additional shares of a company on the basis of a negligently prepared auditor's report could not bring an action against the auditors. For a glimpse at the uncertainties of the extent of liability for negligent misrepresentation in American law, compare the California Court of Appeals' decision in International Mortgage Co. v. John P. Butler Accountancy Corp., 223 Cal. Rptr. 218 (Ct. App. 1986), with the later decision of the California Supreme Court in Bily v. Arthur Young \& Co., 834 P.2d 745 (Cal. 1992).

56. [1992] 1 App. Cas. 310 (1991). The case is discussed supra at note 43.

57. See Jenny Steele, Skepticism and the Law of Negligence, 52 CAMBridge L.J. 437 (1993); see also Howarth, supra note 5.

58. [1993] 3 W.L.R. 354 (H.L.). 
tor had assumed a responsibility to them to act with reasonable care and that, since the testator was dead, if the beneficiaries could not bring an action, there was no other possible way in which the solicitor's failure to exercise reasonable care could be redressed. ${ }^{59} \mathrm{~A}$ few months later, however, a majority of their Lordships held that a surveyor who negligently altered his report to allow a ship to sail with only temporary repairs, instead of the permanent repairs he had previously recommended, had not assumed any such responsibility to the owners of the ship's cargo when the temporary repairs failed and the ship sank. ${ }^{60}$ Their Lordships noted that maritime transactions were accompanied by complex commercial and insurance arrangements and concluded that it would be "unfair, unjust and unreasonable" 61 to impose liability upon the classification society who had supplied the surveyor.

\section{B. American Cases on Economic loss}

The same urge to resolve the question of whether economic loss can be recovered in a tort action by subsuming it under the broader principle of reasonable foreseeability was of course felt in the United States. A small minority of state courts did in fact hold that, in product liability actions, what might be called pure economic loss was indeed recoverable. ${ }^{62} \mathrm{Nev}$ ertheless, over time, even these courts had difficulty with this doctrine. For example, after first holding that a retail purchaser of what was described as "Grade \#1" carpet was able to recover the cost of replacing that carpet from the manufacturer who was several steps removed from the retail purchaser in the distribution scheme and of whose name the purchaser was unaware at the time of purchase, ${ }^{63}$ the New Jersey Supreme Court subsequently refused to apply that doctrine in an action that involved "commercial" parties. ${ }^{64}$

The problems with the foreseeability principle are more starkly revealed in the contortions of the U.S. Court of Appeals for the Second Circuit in In re Kinsman Transit Co. ${ }^{65}$ That case involved the liability arising from the following almost comically bizarre set of facts. A Great Lakes grain ship, over four hundred feet long, was moored for the winter in the Buffalo River, which runs through Buffalo, New York, into Lake Erie. Through the combined negligence of those in charge of the wharf,

59. [1995] 2 W.L.R. 187 (H.L.) (Lord Keith of Kinkel and Lord Mustill were the dissenters).

60. Marc Rich \& Co. v. Bishop Rock Marine Co., [1995] 3 All E.R. 307 (H.L.) (Lord Lloyd of Berwick dissented).

61. Id. at 332 (per Lord Steyn with whose speech all the members of the majority agreed).

62. See, e.g., Santor v. A \& M Karagheusian, Inc., 207 A.2d 305, 312 (N.J. 1965); Oksenholt v. Lederle Labs., 656 P.2d 293, 296-97 (Or. 1982); City of La Crosse v. Schubert, Schroeder \& Assocs., 240 N.W.2d 124, 127 (Wis. 1976). See also J'Aire Corp. v. Gregory, 598 P.2d 60, 64-65 (Cal. 1979), a case very like Junior Books.

63. Santor, 207 A.2d at 314.

64. Spring Motors Distribs. v. Ford Motor Co., 489 A.2d 660 (N.J. 1985).

65. 338 F.2d 708 (2d Cir. 1964), cert. denied, 380 U.S. 944 (1965). 
who failed to properly maintain the deadman, and the ship's watchman, the ship broke her moorings and struck and dislodged another even longer ship. Both ships drifted down the river until they lodged in a draw bridge that, owing to the negligence of the bridge keepers, was only partially raised by the time the ships reached it. Since the channel was only 177 feet wide at this point, the two ships wedged into the bridge and formed a dam in the ice-choked stream that flooded riparian property for three miles back up the river to the starting point of the tragi-comedy.

A majority of the Second Circuit was prepared to allow all of the riparian owners whose property had been flooded to recover. Certainly, to my mind, all these damages were foreseeable consequences of a ship of that size breaking loose from her moorings in an ice-choked river. Nevertheless, the second time the case reached the Court of Appeals, ${ }^{66}$ it held that there was no liability for the economic loss suffered by, among others, those parties whose claim was that, with the river closed to navigation, they were unable to move grain they were contractually bound to deliver to the appropriate dock. Judge Kaufman, however, did not want to rely on the traditional distinction between economic loss and physical loss, which would have easily disposed of the case despite the fact that it would have been difficult to argue that these damages were not reasonably foreseeable consequences of the original negligence. In denying recovery, Judge Kaufman held that the connection between the defendants' negligence and the plaintiffs' damages was "too tenuous and remote" to permit recovery. "In the final analysis," he declared, "the circumlocution whether posed in terms of 'foreseeability, 'duty,' 'proximate cause,' 'remoteness,' etc. seems unavoidable." 67 He concluded by quoting from Judge Andrews' dissenting opinion in the Palsgrafos case that " "[i]t is all a question of expediency . . . of fair judgment." 69 Whether this was a more satisfying basis for deciding the case than simply dismissing the claims because they were pure economic loss is another matter. The subsequent decision of the Supreme Court of the Urited States in East River Steamship Corp. ${ }^{70}$ indicates that, in admiralty cases, such as In re Kinsman Transit Co., the Court at least is content with the traditional distinction.

66. In re Kinsman Transit Corp., 388 F.2d 821, 824-25 (2d Cir. 1968).

67. Id. at 825.

68. Palsgraf v. Long Island R.R., 162 N.E. 99 (N.Y. 1928).

69. 388 F.2d at 825 (quoting Palsgraf, 162 N.E. at 104). In Union Oil Co. v. Oppen, 501 F.2d 558 (9th Cir. 1974), an oil spill case, Judge Sneed also expressed dissatisfaction with the traditional exclusion of recovery for economic loss but then tried to limit the reach of his decision recognizing liability to commercial fishermen for whom there were precedents for allowing recovery on a public nuisance theory. Certainly the losses of resort hotels, which Judge Sneed seemed to want to exclude, are as foreseeable as those of commercial fishermen. Id. at 570 .

70. See supra note 49 and accompanying text. 


\section{Other American Experiments with the Foreseeability} PrinCIPLE

The attempt to find easily articulable and clear statements of principle which supposedly provide for the "just" resolution of cases is, of course, not confined to the maneuverings concerning the issue of recovery for economic loss. An area that, at least in the United States, is giving rise to the same sorts of intellectual fumbling is that concerning so-called derivative actions. Examination of one such instance, which was also driven at least in part by notions of reasonable foreseeability, may be helpful. In Wyco v. Gnodtke, ${ }^{71}$ the Supreme Court of Michigan held that the loss of companionship of a minor child was a compensable item of damages under Michigan's then existing version of Lord Campbell's Act, under which recoverable damages were limited to "pecuniary damages." A few years later in 1970, however, the Supreme Court of Michigan reconsidered the issue, ${ }^{72}$ and the law returned to its pre-Wycko state, in which loss of companionship was not considered "pecuniary" damage. In 1971 the Michigan legislature responded by enacting legislation, effective March 30,1972 , specifically permitting recovery for loss of society and companionship in wrongful death actions. When confronted with the question of what happened with regard to cases that had commenced before March 30, 1972, the Michigan Supreme Court then held that its decision retreating from Wycko was in error. ${ }^{73}$

Subsequent to this minuet, the Supreme Court of Michigan in Berger v. $W_{e b e r}{ }^{74}$ was confronted with the issue of whether a minor child could recover for the loss of the society and companionship of its mother who had been injured but not killed in an automobile accident. The court held that it could and relied on the fact that, under the wrongful death statute, children, as we have just seen, could recover for the loss of society and companionship of a parent who had been killed in such an accident. Given the existing judicial and legislative policies of the state of Michigan, the court concluded that it was only proper that a child's action for the loss of society and companionship of an injured parent should be recognized.

A few years later, however, the Michigan Supreme Court was confronted with the question of whether a parent could bring an action for the loss of the society and companionship of a child that had been injured but not killed. Perhaps to the surprise of some, and the delight of those who felt that the decision recognizing the child's action was unwise, the court refused to allow an action by the parents for the loss of the consortium of an injured child. ${ }^{75}$ The court specifically held that "[f]orseeability

71. 105 N.W.2d 118 (Mich. 1960).

72. Breckon v. Franklin Fuel Co., 174 N.W.2d 836 (Mich. 1970).

73. Smith v. City of Detroit, 202 N.W.2d 300, 303-04 (Mich. 1972).

74. 303 N.W.2d 424 (Mich. 1981).

75. Sizemore v. Smock, 422 N.W.2d 666 (Mich. 1988). 
of injury alone does not mandate recognition of a cause of action."76 Factors such as the explosion in liability costs and the burdens imposed on the courts from multiplying the actions that can arise from a single accident have to be considered. The two dissenters argued that there was no principled way to distinguish the parents' cause of action, which the Court refused to recognize, from the child's cause of action that had previously been upheld. At least one member of the majority agreed with this latter point and argued that the Berger case should be overruled. Here again, we see a court determined to see legal development firmly established on the basis of "principle" forced to retreat and, in this instance, to leave the law in an even more chaotic state than that in which the court had found it.

\section{THE ROLE OF PRINCIPLE IN TORT LAW}

Where does all this leave us? One could continue to maintain that tort law should be directed by clear statements of principle but that the principle of reasonable foreseeability is not the correct one. Or, one could insist that the principle of reasonable foreseeability is the correct principle, but that the courts have made a hash of it. I do not think either of these alternatives will work. To my mind the principle of "reasonable foreseeability" is a good one; it just cannot do all the work that is demanded of it. Moreover, I am extremely doubtful that any better general principle of tort liability could be formulated.

The other possible reaction to the confusing farrago is to scrap the whole exercise. After all, has not Judge Andrews told us that "[i]t is all a matter of expediency?"77 To which I would reply, it all depends on what you mean by "expediency." If by expediency one means "politics"-in the sense in which that term is used to describe the use of power to achieve hegemony in society for a particular ideology or economic or class structure, or, more prosaically, of using power to advance partisan interests, and if the only criterion by which those efforts can be judged is how successful they are-I would answer no. That is to say, I do not accept the assertion that the grading of an examination by a professor or the decision of a case by a judge is the same type of decision as that of a legislature, on the eve of an election, on how to allocate construction funds among competing public work projects.

I am not so naive as to believe that factors such as sex, race, and personal advancement never influence judicial decision-makers. No matter how hard a decision-maker may try, he can never be certain that he is not unconsciously influenced by factors such as these, but the whole point of a system of law is to force the decision-maker to justify his decision according to some legally relevant criteria. In a previous piece, I have argued that a system of strict liability for the miscarriage of an ultra-

76. Id. at 671 .

77. Palsgraf, 162 N.E. at 104 (Andrews, J., dissenting). 
hazardous or abnormally dangerous activity that focuses only on the degree of danger of the activity and the commonness of the activity is different from one in which the social importance of the activity is stated to be a factor of equal value. ${ }^{78}$ It is not that the question of the social importance of the activity will not influence a decision-maker operating under the former system but that such a decision-maker must be able to make a plausible argument that the activity is or is not highly dangerous, whereas a decision-maker under the latter system is not so confined. It is this narrowing of discretion, to which I am certainly not opposed, that is the essence of the rule of law, and the desire so to limit discretion is certainly one of the major attractions of the resort to principle.

There is, however, another view of expediency, one that sees the term

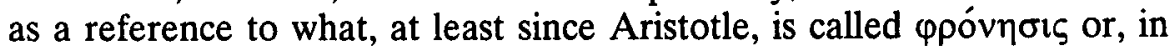
English, practical wisdom. I would like to think that this is what Oliver Wendell Holmes, Jr. had at least partially in mind when he said that "[t]he life of the law has not been logic: it has been experience." this view, principles are not ends in themselves; they are merely devices by which human beings seek to achieve the good life. The goals and values of life are many and diverse. They are often incompatible, as even modern natural lawyers recognize and yet do not feel that they are being unprincipled in so doing. ${ }^{80}$ Principles are useful, even essential, but they are not ultimates. If this type of deliberation is what Judge Andrews had in mind when he said that "[i]t is all a matter of expediency," then he has pointed us in the right direction.

A complex normative system like the law, that is inescapably intertwined with the sometimes contradictory morality of the society in which it operates, requires those who function as officials of that legal system to make choices. The choices these officials make are constrained by notions of consistency-the need to articulate convincing reasons of why two cases are dissimilar; by notions of what Aquinas and the natural lawyers call "the common good"; by notions of efficiency of administration; and by many other considerations including the sorts of principles that torts scholars discuss. As already noted, the law does of course strive to make certain factors (such as, normally, the parties' race or sex) inappropriate for consideration. But to try to make decisions of complex cases depend solely on the application of some single "principle" to the exclusion of all other factors is as unwise as it is unachievable. To try to simplify the process by trying to reduce the choices involved in deciding a case to the application of a verbal formula, such as the principle of reasonable foreseeability, may seem comforting to some but in the end, as we have seen, leads to inconsistent decisions, which only serve to reinforce the cynicism that the appeal to principle was designed to avert. It is not that the verbal formulas thus far chosen were inadequate; it is, rather,

78. George C. Christie, An Essay on Discretion, 1986 Duke L.J. 747, 764-72.

79. Holmes, supra note 3 , at 1.

80. See, e.g., John Finnis, Natural Law and Natural Rights 81-125 (1980). 
that the whole enterprise was doomed from the start. Social life is too rich in complicated details to permit resort to these kinds of overriding abstractions. The best common-law judges have always known this, and their decisions reflect the exercise of seasoned judgment.

If, perhaps under the influence of Ronald Dworkin, ${ }^{81}$ one insists that the law is driven by normative principles that determine the "correct" decision of particular cases, then Lord Scarman's sharp distinction, in $\mathbf{M c}$ Loughlin v. O'Brian, ${ }^{82}$ between principle and policy sounds plausible and Lord Edmund-Davies' insistence that policy has always played a role in the development of the law appears as merely the sad and regrettable reflection of the fact that this is, after all, not the best of all possible worlds. This is unfortunate. If one abandons the illusory insistence that legal development must respond to a single or at most a limited number of principles with normative sweep, then Lord Scarman's stark distinction between principles and economic and social policy disappears. Are not the propositions that economic loss should be left to the contractual arrangements worked out by the parties in the light of commercial law, or that economic loss should be insured against by the parties concerned, every bit as much statements of principle as the proposition that, in the law of torts, the range of interests that are eligible for compensation should be determined by the principle of reasonable foreseeability?

Indeed, the insistence that the foreseeability be "reasonable" is itself capable of bringing in these other factors. "Reasonable" foreseeability has been held to include more than the likelihood of injury; it includes factors such as the burden on the defendant of changing his practices in the light of the foreseeable risk. ${ }^{83}$ Why cannot the notion of reasonableness with regard to foreseeability include the social judgment that it is unreasonable to expect the tortfeasor to worry about the pure economic loss that his conduct may cause as a result of the physical damage his conduct may cause to third parties? To some extent, the law already does that. As far as I know, no court has held that, if $\mathrm{X}$ negligently injures a famous football player, $X$ would be liable in an action brought by the football player's employer for the loss suffered because fewer people bought tickets to the games. Like the loss in Anns and its progeny, this loss of profits is much more foreseeable than the damage for fire loss

81. It does not strike me as mere coincidence that a collection of Dworkin's essays in which he continually espoused the primacy of principle and the difference between principle and policy-Ronald Dworkin, TAKING Rights SERIOUSLY (1977)-had achieved great notoriety by the time Junior Books and McLoughlin v. O'Brian were decided in 1982. In Law's Empire, Dworkin makes frequent reference to the McLoughlin case and makes clear his preference for the "principled" approach taken by Lord Scarman and Lord Bridge of Harwich. Ronald Dworkin, Law's Empire (1986).

82. [1983] 1 App. Cas. 410 (1982).

83. This, after all, is what Wagon Mound II was all about. Overseas Tankship (U.K.) Ltd. v. The Miller Steamship Co., Pty. (Wagon Mound II), [1967] 1 App. Cas. 617 (P.C. 1966) (appeal taken from N.S.W.). See, in particular, id. at 641-44, where the Privy Council incorporated into the reasonable foreseeability test the factors highlighted by Judge Learned Hand in United States v. Carroll Towing Co., 159 F.2d 169, 173 (2d Cir. 1984). 
recovered in Wagon Mound II. But that does not mean that the law must allow recovery in tort for these losses.

Under the reading that I have suggested, of course, the term "reasonable foreseeability" no longer refers to an overriding normative principle driving the decision of concrete cases but refers rather to a mnemonic device for insuring that, in the decision of difficult cases, the decisionmaker makes an appropriately informed choice, a choice that can never be mechanical but must always be governed, as well as constrained, by considerations of consistency ${ }^{84}$ and of fairness, and, if you will, by consideration of principle in the broader sense in which I have used that term. In this broader sense there is of course an important place for principle in tort law. Who could argue that there is not? The problems arise when one asks too much of principles.

Whether or not one is prepared to accept such a broad reading of the notion of reasonable foreseeability, history amply illustrates that the attempt to confine the development of tort law to the application of one overriding normative principle, which insulates the decision-maker from the responsibility for making difficult choices, is the pursuit of a chimera. It inevitably leads to the inconsistent and sometimes incoherent development of the case law that, ironically, the appeal to principle is designed to avoid.

84. In my own work I have stressed the importance of consistency among cases and have asserted that it is easier to decide whether two or more cases are significantly different from each other than to reach agreement on the single principle or rule under which they should be subsumed. See George C. Christie, Objectivity in the Law, 78 YALE L.J. 1311 (1969). I discussed some of the broader implications of this thesis in LAW, NORMS \& AUTHORITY (1982). There is a good related discussion by Raz in which he stresses that what he calls "local coherence" is about all one can expect of a legal system. Joseph Raz, The Relevance of Coherence, 72 B.U. L. REv. 273 (1992). Law, he asserts, is based on authority and involves choices among incommensurate values. Like morality, it can never achieve "global coherence." Id.; see also Jules L. Coleman \& Brian Leiter, Determinacy, Objectivity, and Authority, 142 U. PA. L. REv. 549 (1993). 